\title{
Hubungan Motivasi Diri Pasien TB-MDR terhadap Kepatuhan Minum Obat/Oat di Puskesmas Pelangan Sekotong Barat
}

\author{
Dedi Antoni $^{1 *}$, Yayan Hardiansah ${ }^{1)}$, Fuji Khairani ${ }^{1)}$, Muhammad Amrullah ${ }^{1)}$ \\ Email: dedi08686@gmail.com \\ 1) Universitas Qamarul Huda Badaruddin
}

\begin{abstract}
ABSTRAK
Tuberkulosis adalah suatu penyakit infeksi menular yang disebabkan oleh basil atau bakteri Mycobacterium tuberculosis dengan gejala yang sangat bervariasi. Sebagian kuman TB menyerang paru (TB Paru) tetapi dapat juga menyerang berbagai organ dan jaringan tubuh lainnya. Saat ini penyakit TB masih menjadi masalah di dunia, salah satu masalah dari penyakit ini adalah mengenai program pengobatan. Kendala dalam pengobatan TB adalah kurangnya kepatuhan dan motivasi dari penderita TB untuk minum obat anti tuberkulosis sehingga menyebabkan TB-MDR. Tujuan penelitian ini adalah untuk mengetahui hubungan motivasi diri pasien TB-MDR terhadap kepatuhan minum obat/OAT pada penderita TB di Puskesmas Pelangan Sekotong Barat. Penelitian ini menggunakan metode penelitian observasional analitik dengan rancangan cross sectional. Populasi dalam penelitian ini adalah semua Pasien TB-MDR yang ada di wilayah kerja puskesmas sekotong yang berjumlah 22 orang. Teknik pengambilan sampel pada penelitian ini menggunakan non probability sampling yaitu purposive sampling dengan 16 sampel yang didapatkan berdasarkan kriteria inklusi dan esklusi yang telah ditentukan oleh peneliti. Hasil Analisa uji statistik dengan menggunakan chisqure didapatkan bahwa nilai $\mathrm{p}=0,000$ dan $\alpha<0,05$ sehingga $\mathrm{H}_{1}$ diterima yang artinya ada hubungan antara motivasi terhadap Kepatuhan Minum Obat/OAT pada Pasien TB-MD.
\end{abstract}

Kata kunci: Motivasi, Kepatuhan, Tuberkulosis

\begin{abstract}
Tuberculosis is an infectious infectious disease caused by the bacillus or bacteria Mycobacterium tuberculosis with very varied symptoms. Some TB germs attack the lungs (pulmonary TB) but can also attack various organs and other body tissues. Currently TB disease is still a problem in the world, one of the problems of this disease is regarding the treatment program. The obstacle in TB treatment is the lack of adherence and motivation of TB patients to take anti-tuberculosis drugs, causing MDR-TB. The purpose of this study was to determine the relationship of self-motivation of MDR-TB patients to adherence to taking medication/OAT in TB patients at the Pelangan Health Center in West Sekotong. This study used an analytical observational research method with a cross sectional design. The population in this study were all 22 MDR-TB patients in the working area of the Sekotong Public Health Center. The sampling technique in this study used non-probability sampling, namely purposive sampling with 16 samples obtained based on the inclusion and exclusion criteria determined by the researcher. The results of statistical test analysis using chisqure found that the value of $p=0.000$ and $<0.05$ so that $\mathrm{H} 1$ was accepted, which means that there is a relationship between motivation to take medication/OAT adherence in TB-MDR patients.
\end{abstract}

Keywords: Motivation, Compliance, Tuberculosis 


\section{A. LATAR BELAKANG}

TBC adalah suatu penyakit menular yang disebabkan oleh kuman Mycobacterium tuberculosis. Terdapat beberapa spesies Mycobacterium, antara lain: M. tuberculosis, $M$. africanum, $M$. bovis, M. leprae dan sebagainya. Sebagian besar dari bakteri ini menginfeksi paru, tetapi juga dapat mengenai organ tubuh lain. TBC paru merupakan penyakit menular yang paling berpengaruh sebagai penyebab morbiditas dan mortalitas, termasuk angka kejadian di Indonesia [1].

Indonesia merupakan salah satu negara yang mempunyai beban TBC yang terbesar diantara 5 negara yaitu India, Indonesia, China, Philippina and Pakistan (Global Tuberculosis Report, 2017). Selain itu terdapat tantangan yang perlu menjadi perhatian yaitu meningkatnya kasus Tuberkulosis-HIV, Tuberkulosis dengan DM, Tuberkulosis pada anak dan masyarakat rentan lainnya. Hal ini memacu pengendalian TBC nasional terus melakukan intensifikasi, akselerasi, ekstensifikasi dan inovasi program. Berdasarkan Global Report Tuberculosis tahun 2017, secara global kasus baru TBC sebesar 6,3 juta, setara dengan $61 \%$ dari insiden TBC $(10,4$ juta). TBC tetap menjadi 10 penyebab kematian tertinggi di dunia dan kematian TBC secara global diperkirakan 1,3 juta pasien [2]

Berdasarkan Global Tuberculosis Report [2], angka insiden TBC Indonesia 391 per 100.000 penduduk dan angka kematian 42 per 100.000 penduduk sedangkan menurut pemodelan yang berdasarkan data hasil survei prevalensi TBC tahun 2013-2014 angka prevalensi pada tahun 2017 sebesar 619 per 100.000 penduduk sedangkan pada tahun 2016 sebesar 628 per 100.000 penduduk. Berdasarkan data Kemenkes RI, Jawa Barat menempati urutan ke-6 dari 34 provinsi dengan presentase $53,2 \%$ dari jumlah kasus TB sebanyak 425.089 kasus [1].

Angka kejadian TBC cukup tinggi di Indonesia. Penderita TBC diharuskan meminum Obat Anti TBC. Obat TBC harus diminum oleh penderita secara rutin selama enam bulan berturut-turut tanpa henti. Kedisiplinan pasien dalam menjalankan pengobatan juga perlu diawasi oleh anggota keluarga terdekat yang tinggal serumah, yang setiap saat dapat mengingatkan penderita untuk minum obat. Apabila pengobatan terputus tidak sampai enam bulan, penderita sewaktu-waktu akan kambuh kembali penyakitnya dan kuman TBC menjadi resisten sehingga membutuhkan biaya besar untuk pengobatannya (Faustini dalam Sarwani, 2016). Pengobatan TBC dilakukan selama enam bulan secara rutin. Pengobatan yang terputus atau tidak sesuai dengan standar DOTS dapat menyebabkan kekambuhan penyakit dan kemungkinan terjadinya resistensi sekunder kuman TB terhadap obat anti TBC atau Multi Drug Resistance (MDR) [3].

MDR-TB merupakan permasalahan utama di dunia. Banyak faktor yang memberikan kontribusi terhadap resistensi obat pada negara berkembang termasuk ketidaktahuan penderita tentang penyakitnya, kepatuhan penderita buruk, pemberian monoterapi atau regimen obat yang tidak efektif, dosis tidak adekuat, instruksi yang buruk, keteraturan berobat yang rendah, motivasi penderita kurang, suplai obat yang tidak teratur, bioavailibity yang buruk dan kualitas obat memberikan kontribusi terjadinya resistensi obat sekunder.

MDR-TB didefinisikan sebagai resistensinya dua obat anti TB paling penting pada terapi TB lini pertama, yaitu rifampisin dan isoniazid. Pengobatan obat yang tidak adekuat pada individu dengan TB akan membunuh sebagian besar bakteri namun akan memungkinkan pertumbuhan sejumlah kecil organisme resisten di dalam populasi bakteri yang timbul. Bila pengobatan yang tidak memadai terus dilakukan maka sejumlah kecil organisme yang telah bermutasi akan memiliki resistensi terhadap obat lain secara berurutan dan berkembang menjadi resistensi terhadap banyak obat anti TB [4]. Dengan adanya MDRTB maka masa pengobatan menjadi lebih 
panjang. Pengobatan dilakukan selama 24 bulan yang terdiri dari 8 bulan fase intensif dan 16 bulan fase lanjutan [5].

Kendala dalam pengobatan TB adalah kurangnya kepatuhan dari penderita TB untuk minum obat anti tuberkulosis, penyebabnya yaitu motivasi dari para penderita yang masih kurang [6]. Menurut hasil penelitian [7] ketidak patuhan berobat dan motivasi penderita yang rendah memberikan kontribusi terhadap terjadinya MDR-TB. Dari hasil studi pendahuluan yang dilakukan pada 5 responden penderita Tuberkulosis (TB), diantaranya mengatakan tidak kuat untuk minum obat/OAT, di sebabkan tidak biasa menahan efek samping dari obat/OAT. Responden merasa nyeri di bagian ulu hati, mual dan muntah ketika beberapa saat setelah minum obat/OAT. Berdasarkan studi pendahuluan yang dilakukan maka peneliti tertarik untuk melakukan penelitian dengan judul Hubungan Motivasi Diri Pasien TB-Lanjutan Terhadap Kepatuhan MinumObat/OAT Di Puskesmas Pelangan Sekotong Barat 2020

\section{B. METODE PENELITIAN}

Penelitian ini menggunakan metode penelitian observasional analitik dengan rancangan cross sectional. Penelitian ini dilakukan di Puskesmas Pelangan Sekotong Barat tahun 2020. Populasi pada penelitian ini adalah semua pasien yang menderita TB di wilayah kerja Puskesmas Pelangan Sekotong Barat sebanyak 22 orang. Pengambilan sampel pada penelitian ini menggunakan teknik non probability sampling yaitu purposive sampling dengan jumlah sampel sebanyak 16 sampel yang didapatkan dari criteria inklusi dan eksklusi yang sudah ditentukan oleh peneliti.

Data yang dikumpulkan dalam penelitian ini adalah data karakteristik responden (jenis kelamin, umur dan Pendidikan, pekerjaan) dilakukan dengan cara wawancara langsung dan observasi kepada responden dan mengukur motivasi serta kepatuhan minum obat pada penderita dengan menggunakan kuesioner.
Analisa yang digunakan pada penelitian ini ada dua yaitu:

1. Analisa Univariant

Analisa univariat merupakan analisa yang dilakukan pada setiap variabel yang dinyatakan dengan menggambarkan dan meringkas data dengan cara ilmiah dalam bentuk tabel atau grafik [8].

Variable pada penelitian ini meliputi variable independen yaitu motivasi diri dan variable dependen kepatuhan minum obat pada pasien TB-MDR. Teknik analisa data yang digunakan analisis data univariat yang bertujuan menghasilkan distribusi frekuensi dan persentase dari setiap variabel penelitian. Setelah setiap item diberi nilai, kemudian dilakukan tabulasi. Setelah ditabu-lasikan kemudian dihitung distribusi frekuensi dan presentasi dari setiap variabel penelitian. Hasil analisis univariat dengan skala ordinal disajikan dalam bentuk tabel distribusi frekuensi yang dinyatakan dalam persentase [9].

2. Analisa Bivariat

Analisa Bivariat digunakan untuk melihat ada tidaknya hubungan variable independen dan variable dependen dengan kesembuhan penderita TB- MDR pada kegiatan di Puskesmas Pelangan Sekotong Barat. Dengan menggunakan uji chi square dengan tingkat kemaknaan $(\alpha=0,05)$

\section{HASIL DAN PEMBAHASAN}

1. Karaktristik responden berdasarkan jenis kelamin

Tabel.1 Distribusi Responden Berdasarakan Jenis kelamin

\begin{tabular}{llll}
\hline No & JenisKelamin & Jumlah (f) & $\%$ \\
\hline 1 & Laki-laki & 11 & 68,75 \\
\hline 2 & Perempuan & 5 & 31,25 \\
\hline Total & 16 & 100 \\
\hline
\end{tabular}

Berdasarkan tabel. 1 didapatkan $11(68,75 \%)$ responden berjenis kelamin laki-laki dan 5 responden $(31,25 \%)$ berjenis kelamin perempuan 
2. Karaktristik responden berdasarkan Umur

Tabel.2 Distribusi Responden Berdasarkan Umur

\begin{tabular}{llll}
\hline No & Umur & $\begin{array}{l}\text { Jumlah } \\
\text { (f) }\end{array}$ & $\%$ \\
\hline 1 & Tua (>50) & 4 & 25,0 \\
\hline 2 & $\begin{array}{l}\text { Muda (12- } \\
\text { 50) }\end{array}$ & 12 & 75,0 \\
\hline \multicolumn{2}{l}{ Total } & 16 & 100,0 \\
\hline
\end{tabular}

Berdasarkan tabel. 2 didapatkan 4 responden (25\%) berumur tua dan 12 responden $(75 \%)$ berumur muda.

3. Karaktristisk responden berdasarkan Pendidikan

Tabe 1.4 Distribusi Responden Berdasarkan

\begin{tabular}{clcc} 
& Pendidikan & & \\
\hline No & Pendidikan & $\begin{array}{c}\text { Jumlah } \\
\text { (f) }\end{array}$ & $\%$ \\
\hline 1 & $\begin{array}{l}\text { Rendah } \\
\text { (tidaksekolah, } \\
\text { Tamat SD- } \\
\end{array}$ & 14 & 87,5 \\
& & \\
& Tamat SMA \\
\hline 2 & $\begin{array}{l}\text { Tinggi (D3, } \\
\text { Sarjana) }\end{array}$ & 2 & 12,5 \\
\hline Total & 16 & 100,0 \\
\hline
\end{tabular}

Berdasarkan tabel. 4 didapatkan 14 responden $(87,5 \%)$ berpendidikan Rendah dan 2 responden $(12,5 \%)$ berpendidikan tinggi.

4. Analisa Bivariat

a. Motivasi Responden

Tabel.5 Distribusi Motivasi Responden

\begin{tabular}{llll}
\hline Variabel & Kategori & F & $\%$ \\
\hline Motivasi & Baik & 10 & 62,5 \\
\hline & Cukup & 6 & 37,5 \\
\hline Total & & 16 & 100,0 \\
\hline
\end{tabular}

Berdasarkan tabel.5 didapatkan ada 10 reponden $(62,5 \%)$ memiliki motivasi baik sedangkan 6 responden $(37,5 \%)$ memiliki motivasi cukup.

b. Kepatuhan responden dalam mengkonsumsi Obat TB
Tabe 1.6 Distribusi Kepatuhan Responden dalam minum Obat TB

\begin{tabular}{llll}
\hline Variabel & Kategori & $\mathrm{F}$ & $\%$ \\
\hline Kepatuhan & Patuh & 12 & 75,0 \\
\hline & TidakPatuh & 4 & 25,0 \\
\hline Total & & 16 & 100 \\
\hline
\end{tabular}

Berdasarkan tabel. 6 didapatkan bahwa $12(75 \%)$ responden patuh untuk minum obat sedangkan 2 responden (25\%) tidak patuh.

c. Hubungan Motivasi Diri Terhadap Kepatuhan Minum Obat

Tabel.5 Distribusi Hubungan Motivasi responden terhadap kepatuhan minum obat

\begin{tabular}{lllllll}
\hline \multirow{2}{*}{ Motivasi } & \multicolumn{6}{l}{ Kepatuhan Minum Obat } \\
& \multicolumn{7}{c}{ Total } \\
\cline { 2 - 5 } & \multicolumn{2}{l}{ Patuh } & $\begin{array}{c}\text { Tidak } \\
\text { Patuh }\end{array}$ \\
\hline \multirow{2}{*}{ Tinggi } & F & $\%$ & F & $\%$ & F & $\%$ \\
& 1 & 68,7 & 0 & 0 & 1 & 68, \\
& 1 & 5 & & & 1 & 75 \\
\hline Rendah & 3 & 18,7 & 2 & 12, & 5 & 31, \\
& & 5 & & 5 & & 25 \\
\hline Kurang & 0 & 0 & 0 & 0 & 0 & 0 \\
\hline Total & 1 & 93,7 & 2 & 12, & 1 & 100 \\
& 4 & 5 & & 5 & 6 &
\end{tabular}

Uji Chisquare $\mathrm{p}=0,000$

Berdasarkan hasil uji statistic dengan menggunakan chisqure di peroleh hasil $\mathrm{p}=$ 0,000 dengan menetapkan hasil signifikansi $\alpha<0,05$ maka H1 diterima yang berarti ada hubungan antara motivasi terhadap kepatuhan minum Obat/OAT pada pasien TB-Multi-Drug Resistant (MDR).

Hasil penelitian yang didapatkan menunjukan bahwa motivasi memiliki hubungan terhadap kepatuhan minum obat/OAT Pada Pasien TB-MDR di Puskesmas Pelangan Sekotong Barat. Berdasarkan data yang di peroleh, sebagian responden memiliki motivasi yang baik dalam mencapai kesembuhan, dan sebagian 
lainnya memiliki motivasi cukup. Responden yang memiliki motivasi baik cendrung patuh dalam minum obat/OAT TB-MDR. Hal ini juga di dukung dengan penelitian yang di lakukan oleh [10]. Bahwa motivasi pasien TB-MDR dalam mencapai kesembuhan memiliki hubungan dengan kepatuhan minum obat. Penelitian dari [6] menyampaikan bahwa terdapat hubungan yang signifikan antara motivasi dengan kepatuhan berobat dan juga minum obat pada pasien TB [6]. Juga menyampaikan bahwa motivasi pasien TB dalam melaksanakan program pengobatan dan juga minum obat dipengaruhi banyak factor diantaranya: pengetahuan dan tingkat pendidikan.

\section{Motivasi pasien TB-MDR} dipengaruhi oleh dua hal yakni dari dalam diri penderita TB-MDR itu sendiri dengan ada dorongan, keinginan untuk berobat dan melakukan sesuatu yang lebih baik dan dukungan dari keluarga, serta masyarakat maupun petugas kesehatan dalam menangani kasus penyakit TB-MDR tersebut melalui pendidikan kesehatan, member support, dorongan sesuai tujuan yang di harapkan. Motivasi di katakan baik bila mana seseorang mampu untuk mengendalikan dirinya menuju hal yang baik. Untuk meningkatkan motivasi perlu adanya penyuluhan penyakit dan bahayanya penyakit tersebut terhadap ancaman kehidupan manusia [11].

Dari Hasil penelitian yang dilakukan, tidak ada satupun responden yang memiliki motivasi kurang, berdasarkan penelitian yang telah dilakukan sebagian besar responden selalu mendapatkan dukungan dari keluarga dan orang terdekat mereka agar bias mencapai kesembuhan, selain itu petugas Puskesmas Pelangan Sekotong Barat juga selalu memberikan motivasi dan dukungan kepada seluruh pasien agar tidak pernah berhenti dalam minum obat dan juga agar selalu rutin dalam menjalankan pemeriksaan dan pengobatan agar mencapai kesembuhan.

\section{KESIMPULAN}

Tingkat motivasi diri responden tuberculosis-MDR yaitu 10 responden $(62,5 \%)$ memiliki motivasi tinggi, dan 6 responden $(37,5 \%)$ memiliki motivasi cukup. Tingkat kepatuhan minum obat responden tuberkulosisMDR yaitu 12 responden $(75,0 \%)$ patuh, dan 4 responden (25.0\%) tidak patuh. Hasil uji statistik dengan menggunakan chisqure diketahui bahwa nilai $\mathrm{p}=0,000$ yaitu $<0,05$ sehingga $\mathrm{H}_{1}$ diterima yang artinya ada hubungan motivasi terhadap kepatuhan minum Obat/OAT ada pasien TB-MD.

\section{E. UCAPAN TERIMA KASIH}

Terimakasih saya ucapakan kepada Universitas Qamarul Huda Badaruddin yang telah membantu peneliti dalam kelancaran penelitian dengan dukungan biaya penelitian kepada tim peneliti yang diberikan secara bertahap selama 6 bulan dari bulan Juni 2020 sampai dengan Desember 2020. Juga kepada tim dari LPMI yang telah memberikan masukan terkait proses penelitian ini serta turut serta mengevaluasi berjalanya proses penelitian.

\section{DAFTAR PUSTAKA}

[1] Kementerian Kesehatan Republik Indonesia. (2017). Profil Kesehatan Indonesia. Jakarta: Kemenkes RI.

[2] World Health Organization. (2017) Global tuberculosis report. Geneva: WHO

[3] Aristiana, C. D., \& Wartono, M. (2018). Faktor-faktor yang mempengaruhi kejadian Multi Drug Resistance Tuberkulosis (MDR-TB). Jurnal Biomedika dan Kesehatan, 1(1), 65-74.

[4] Steingart K.R., Schiller I., Horne D.J., Pai M., Boehme C.C., Dendukuri N. Xpert ${ }^{\circledR}$ MTB/RIF assay for pulmonary tuberculosis and rifampicin resistance in adults. Cochrane Database of Systematic Reviews. 2014. Issue 1

[5] Astri SDA. (2014). Masalah tuberkulosis resisten obat. Cermin Dunia Kedokteran. 41(4): 248-49

[6] Praetya, J. (2009). Hubungan Motivasi Pasien TB dengan Kepatuhan Dalam 
Mengikuti Program Sistem DOTS di Wilayah Puskesmas Genuk, 46-53.

[7] Sarwani SR, D., \& Nurlaela, S. (2012). Faktor risiko multidrug resistant tuberculosis (MDR-TB). Jurnal Kesehatan Masyarakat, 8 (1), 60-66.

[8] Nursalam, J. (2016). Metodologi Penelitian Ilmu Keperawatan Jakarta: Salembang Medika.

[9] Azwar,S. (2013). Metode Penelitian. Yogyakarta: Pustaka Pelajar.

[10] Nurwidji. Fajri, T. (2013). Hubungan Motivasi Kesembuhan dengan Kepatuhan Penatalaksanaan Pengobatan pada Pasien TB Paru Di Wilayah Kerja Puskesmas Mojosari Mojokerto. Medica Majapahit, 5(2). $68-82$.

[11] Maulidia, D. (2014). Hubungan Antara Dukungan Keluarga dan Kepatuhan Minum Obat Pada Penderita Tuberculosis di Wilayah Ciputat. UIN Syarif Hidayatullah: Jakarta. 